\title{
Science Teachers' Self-efficacy in Instruction and Self-efficacy in Student Engagement across Estonia, Japan, and Turkey
}

\begin{tabular}{ccc}
\hline Article Type & Received Date & Accepted Date \\
Research & 11.04 .2020 & 21.07 .2020 \\
\hline
\end{tabular}

\section{Eren Ceylan*}

\begin{abstract}
Self-efficacy of science teachers has attracted many researcher interest since its association with teachers' quality of instruction, teachers' job satisfaction, and student's achievement and motivation. Therefore, it is very crucial to investigate the factors that affect science teacher's selfefficacy beliefs such as the components of school climate, the indicators of sources of self-efficacy, and teachers' background characteristics. In this respect, this study was carried out to reveal the effect of a set of variables such as professional collaboration among teachers, teacher-student relation, disciplinary climate, needs for professional development in subject matter and pedagogy, workplace well-being and stress, experience of teachers, and gender of teachers on science teachers' self-efficacy in instruction and self-efficacy in student engagement in Estonia, Japan, and Turkey. The variables of this study were gathered from the TALIS 2018. Multiple Logistic Regression was run to estimate the science teachers' odds of having high self-efficacy in instruction and in student engagement across three countries. The results revealed that whereas significant odds ratios were yielded for some of variables related to school climate, sources of self-efficacy and teachers' backgrounds, the magnitudes of the odds ratios show some variations across the countries.
\end{abstract}

Keywords: Science teachers' self-efficacy, school climate, TALIS 2018, sources of self-efficacy.

\footnotetext{
* Corresponding Author: Associate Professor, Ankara University, Faculty of Educational Sciences, Elemantary Education Department, Ankara, Turkey. E-mail: ernceylan@gmail.com https://orcid.org/0000-0001-8244-8260
} 


\title{
Estonya, Japonya ve Türkiye'deki Fen Öğretmenlerinin Öğretimdeki ve Öğrenci Motivasyonundaki Öz-yeterlikleri
}

\begin{tabular}{ccc}
\hline Makale Türü & Başvuru Tarihi & Kabul Tarihi \\
Araştırma & 11.04 .2020 & 21.07 .2020 \\
\hline
\end{tabular}

\section{Eren Ceylan*}

\begin{abstract}
$\ddot{O} \mathbf{z}$
Öğretimin kalitesiyle, öğretmenlerin iş tatminleriyle, öğrenci başarısı ve motivasyonuyla oldukça alakalı olan fen öğretmenlerinin öz-yeterliliği birçok araştırmacının ilgisini çekmiştir. Bu nedenle, fen öğretmenlerinin öz-yeterlik inanışlarını etkileyen okul iklimini oluşturan bileşenler, öz-yeterlik kaynaklarının göstergeleri ve öğretmen özellikleri gibi etmenleri incelemek oldukça önemlidir. Bu bağlamda, bu çalışma Estonya, Japonya ve Türkiye'de bulunan fen öğretmenlerinin özyeterliklerine öğretmenler arası iş birliği, öğretmen öğrenci ilişkileri, disiplin iklimi, öğretmenlerin alan ve pedagoji bilgisine yönelik mesleki gelişim ihtiyaçları, işyerinde iyi hissetme ve stres, öğretmen deneyimi ve cinsiyet gibi değişkenlerin etkisini ortaya çıkarmak için yapılmıştır. Bu çalışmada TALIS 2018 verileri kullanılmıştır. Bu üç ülkede, fen öğretmenlerinin öğretim ve öğrenci motivasyonunda yüksek öz-yeterlikte bulunma olasılıkları çoklu lojistik regresyon analizi ile kestirilmiştir. Bulgular, okul iklimi, öz-yeterlik kaynakları ve öğretmen özellikleriyle alakalı bazı değişkenler için anlamlı olasılık oranları gösterse de bu olasılık oranlarının büyüklükleri ülkeler arasında farkl1lı göstermektedir.
\end{abstract}

Anahtar Sözcükler: Fen öğretmenlerinin öz-yeterlikleri; okul iklimi; TALIS 2018, öz-yeterlik kaynakları.

\footnotetext{
* Sorumlu Yazar: Doç. Dr., Ankara Üniversitesi Eğitim Bilimleri Fakültesi Temel Eğitim Bölümü, Ankara, Türkiye. E-posta: ernceylan@gmail.com, https://orcid.org/0000-0001-8244-8260
} 


\section{Introduction}

Being one of the essential characteristics of teachers and having a potential of being associated with teachers' quality of instruction which is directly related to the students motivation and achievement, self-efficacy of teachers have attracted many researchers interest in the field of education (Holzberger, Philipp and Kunter, 2013). In addition to the robust relations with students' educational outcomes, the association of self-efficacy with the teachers' job satisfaction which is also effects teachers' burnout and their well-being was also expressed in the literature (Skaalvik and Skaalvik, 2010).

Self-efficacy beliefs was defined as the individual perceptions of their ability to successfully plan and carry out a particular courses of action (Bandura, 1997). It was stated that although self-efficacy beliefs are affected by external factors, these beliefs are self-referent which means subjective inferences about one's own ability (Usher and Pajares, 2008). Different self-efficacy beliefs may emerge in different teaching environment and different teaching practices (Klassen et al., 2011; Malinen et al., 2013). Therefore, it was argued that teacher self-efficacy in teaching is not a construct that have only one dimension. Multidimensional framework which includes three self-efficacy core factors such as self-efficacy in instruction, self-efficacy in student engagement, and self-efficacy in classroom management was proposed to investigate teachers' self-efficacy in an accurate way (Klassen et al., 2011).

Although few things are known about the sources of teachers' self-efficacy function into the practice, the sources of self-efficacy were categorized into four as mastery experience, verbal persuasion, vicarious experience, and physiological arousal (Bandura, 1997; Tschannen-Moran et al., 1998). Mastery experiences defined as the authentic experiences that a person performs an ability to sustain and succeed the task. So, the association of higher self-referent subject matter knowledge and higher levels of self-efficacy was reported in the literature (Rice and Roychoudhury, 2003). Second source of self-efficacy was defined as vicarious experiences which refer to see or observe a person succeed a task. The third source of self-efficacy was stated as verbal persuasion which refer a significant person's faith about one's capabilities. Reaction of stress, fatigue, and mood refers to the fourth source of self-efficacy: physiological arousal (Bandura, 1997). In addition, Bandura (2012) expressed that the circumstances in which a given task is performed effects the one's self-efficacy. Therefore, school climate refers the circumstances in which teaching occurs has a great potential to influence teachers' self-efficacy. In some studies, school climate has been used as a mediator between self-efficacy and teachers job satisfaction (Malinen \& Savolainen, 2016).

Science teachers' self-efficacy was investigated in many studies (Petersen and Treagust, 2014; Tosun, 2000) and it was reported that science teachers' low self-efficacy causes expository methods rather than inquiry to be used in science teaching (Palmer, Dixon \& Archer, 2015). In the recent years, the opportunities inserted to the science method courses to enhance teacher candidate's self-efficacy by exposing them to the practices in science teaching (Settlage, Southerland, Smith, \& Ceglie, 2009). But, the results of these initiatives have not indicated the effectiveness on teachers' self-efficacy yet.

Teaching and Learning International Survey (TALIS) which is carried out lastly in 2018 with the participation of 48 countries at lower secondary level presents researchers fruitful opportunities to investigate broad issues related to the teachers such as teachers' instructional practices and teachers' professional practices, teachers' background and initial preparation, teacher's self-efficacy, and teachers' job satisfaction and motivation (Ainley and Carstens, 2018). In TALIS 2018, teachers' selfefficacy was approached in a multidimensional framework which covers self-efficacy in instruction, self-efficacy in student engagement, and self-efficacy in classroom managements. In addition, TALIS 2018 covers constructs related to school climate which can be associated with the dimensions of teachers' self-efficacy such as professional collaboration among teachers in the school, teacher-student relation, and teachers perceived disciplinary climate in school. Moreover, TALIS 2018 also presents some constructs related to sources of teachers' self-efficacy such as teachers need of professional development in content and pedagogy, and their workplace well-being and stress which are strongly related to mastery experience and physiological condition. 
In the literature, many studies were conducted to reveal the potential sources of self-efficacy by investigating the association of science teachers' self-efficacy with the related dimensions (Holzberger, Philipp and Kunter, 2013; Skaalvik and Skaalvik, 2010). In addition, many studies were carried out to investigate the way of enhancing the science teachers' self-efficacy (Avery \& Meyer, 2012; Ford, Fifield, Madsen, \& Qian, 2013). However, few studies were conducted to focus international large-scale assessments to investigate the dimensions of teacher self-efficacy by comparing different countries. In this study, the effects of the variables related to school climate, sources of self-efficacy, and teacher backgrounds on science teachers two self-efficacy dimensions, namely self-efficacy in instruction and self-efficacy in students engagement, were investigated across Estonia, Japan, and Turkey. In this respect, it is believed that this study has a potential to contribute the literature about the science teacher self-efficacy by taking consideration into cultural and educational system variations among three countries.

\section{Purpose of the Study and Research Questions}

The relation of the science teachers' self-efficacy dimensions with some of the indicators of the sources of self-efficacy and science teachers' views on school climate and teachers' background characteristics were scrutinized in Estonia, Japan, and Turkey, respectively. In other words, the similarities and discrepancies of the effects of school climate, sources of self-efficacy, and teachers' backgrounds on different dimensions of self-efficacy such as teachers self-efficacy in student engagement and teachers self-efficacy in instruction was examine for three countries. This study was carried out by using the lower secondary level science teachers views at TALIS 2018 (Teaching and Learning International Survey 2018) in Estonia, Japan, and Turkey. The research question can be stated more specifically as follow:

1) Do the presence of teachers professional collaboration, good relations between students and teachers, presence of disciplinary climate in class, teachers need of professional development in content and pedagogy, presence of stress in the workplace, teachers' gender, and teachers' experience have an effect of science teachers' self-efficacy in students engagement in Estonia, Japan, Turkey?

2) Do presence of teachers professional collaboration, good relations between students and teachers, presence of disciplinary climate in class, teachers need of professional development in content and pedagogy, presence of stress in the workplace, teachers' gender, and teachers' experience have an effect of science teachers' self-efficacy in instruction in Estonia, Japan, Turkey?

\section{Method}

\section{Participants}

More than 100000 teachers from 48 countries participated TALIS 2018 at lower secondary level. In TALIS 2018, a stratified two-staged probability sampling design was used to determine participants in each country. In the first stage, the selection of schools were took place randomly in each country and in the second stage, teachers were randomly selected from the schools selected at the first stage.

This study was carried out based on the lower secondary level science teachers view in Estonia, Japan, and Turkey. The rationale for the selection of these countries can be explained as the performances of these countries in PISA 2018 (Programme for International Student Assessment). Whereas Japan, located at east Asia, has the highest country mean score (530) in science literacy among the OECD countries, Estonia, located at Europe, has the second highest mean score (529) in science literacy among the OECD countries in PISA 2018. On the other hand, whereas Turkey, located as a bridge between Europe and Asia, performed under the OECD average (468), has a higher average when compare to the previous PISA (OECD, 2019a). Therefore, by involving of these countries to this study, the teachers' views will be analyzed not only align with performances of the countries, but also will be discussed regarding to variations of cultural and educational system among three countries.

The total number of the teachers who were involved in TALIS 2018 are 3004, 3555, and 3952 in Estonia, Japan, and Turkey, respectively. The percentage of female teachers are $83,3 \%, 42,2 \%$, and $55,8 \%$ in Estonia, Japan, and Turkey, respectively. For purpose of the study, science teachers at lower secondary level were selected from each of the countries. The numbers of the science teachers who 
participated TALIS 2018 at lower secondary level are 541, 498, and 598 in Estonia, Japan, and Turkey, respectively.

\section{Instrument and Variables}

Teaching and Learning International Survey (TALIS 2018) covers many items related to teachers views and perceptions. The TALIS 2018 database included not only items as variables, it also covers scale scores or index scores of the latent variables which were produced based on group of items. The process of the calculation of these scale and index scores were described in detail with the OECD documents (OECD, 2019b). The dependent variables and the explanatory variables were described as follows:

\section{Dependent Variables}

Self-efficacy in instruction: This latent variable was produced by asking teachers to what extent they can do the following (OECD, 2019b):

(a) Craft good questions for students

(b) Use a variety of assessment strategies

(c) Provide an alternative explanation, for example when students are confused

(d) Vary instructional strategies in my classroom

The response alternatives of these items were designed as: "Not at all" (1), "To some extent" (2), "Quite a bit" (3), "A lot" (4). The omega coefficients, which the critical value was indicated as 0.70 (OECDb, 2019), of the latent construct were calculated as 0.77, 0,79, 0,82 for Estonia, Japan, and Turkey, respectively. Two response alternative as "low self-efficacy" and "high self-efficacy" was produced by recoding response alternatives. The combination of "not at all" and "to some extent" was labelled as "low self-efficacy" $(0)$ and the combination of "quite a bit" and "a lot" was combined to was labelled as "high self-efficacy" (1).

Self-efficacy in student engagement: Teachers were asked to what extent they can do the following:

(a) Get students to believe they can do well in schoolwork

(b) Help students value learning

(c) Motivate students who show low interest in schoolwork

(d) Help students think critically

The response alternatives were with the previous dependent variable: "Not at all" (1), "To some extent" (2), "Quite a bit" (3), "A lot" (4). The omega coefficients were calculated as $0.73,0.72$, and 0.81 for Estonia, Japan, and Turkey, respectively. The response alternatives of "not at all" , "to some extent" were combined and recoded to create the "low self -efficacy" $(0)$ and "quite a bit" "a lot" were combined and recoded to create "high self-efficacy" (1).

\section{Explanatory Variables}

Professional collaboration in lessons among teachers: Teachers were asked to indicate the frequency of doing in the school the following items which constitutes this latent construct:

(a) Teach jointly as a team in the same class

(b) Provide feedback to other teachers about their practice

(c) Engage in joint activities across different classes and age groups (e.g. projects)

(d) Participate in collaborative professional learning

The response options of these items were presented as: Never" (1), "Once a year or less" (2), "24 times a year" (3), "5-10 times a year" (4), "1-3 times a month" (5), "Once a week or more" (6). The omega coefficients were calculated as $0.66,0.65$, and 0.77 for Estonia, Japan, and Turkey, respectively. The response alternatives of Never" (1), "Once a year or less" (2) were combined to indicate "no collaboration" $(0)$ and the other alternative responses were combined to indicate "collaboration" (1). 
Teacher-student relations: The items included in this latent construct were presented to teachers by asking whether they agree these items that happens in the school. The items were presented as follows:

(a) Teachers and students usually get on well with each other.

(b) Most teachers believe that the students' well-being is important.

(c) Most teachers are interested in what students have to say.

(d) If a student needs extra assistance, the school provides it.

The response alternatives were designed as "strongly disagree" (1), "disagree" (2), "agree" (3), "strongly agree" (4).The omega coefficients of the latent variable were calculated as $0,81,0,87$, and 0.88 for Estonia, Japan, and Turkey, respectively. The response alternatives of strongly disagree and strongly agree were combined to express "poor relations" (1) and the response alternatives of agree and strongly agree were combined to indicate "good relations" $(0)$.

Teachers perceived disciplinary climate: The items constitute this latent construct were presented to teachers by asking how strongly they agree or disagree statements (items) that happens in the school. The items were presented as follows:

(a) When the lesson begins, I have to wait quite a long time for students to quieten down

(b) Students in this class take care to create a pleasant learning atmosphere

(c) I lose quite a lot of time because of students interrupting the lesson

(d) There is much disruptive noise in this classroom

The response alternatives were presented from "strongly disagree" to "strongly agree". The omega coefficients of this latent construct were calculated as $0.91,0.88$, and 0.90 for Estonia, Japan, and Turkey, respectively. The response alternatives of strongly disagree and strongly agree were combined to express "disciplined" (1) and the response alternatives of agree and strongly agree were combined to indicate "no discipline" (0).

Needs for professional development in subject matter and pedagogy: The items that were presented to constitute this latent variables were presented to the teachers by asking the teachers' need to the professional development. The items were stated as follows:

(a) Knowledge and understanding of my subject field(s)

(b) Pedagogical competencies in teaching my subject field(s)

(c) Knowledge of the curriculum

(d) Student assessment practices

(e) Student behaviour and classroom management

The response alternatives that were presented after these items designed as no need at present" (1), "Low level of need (2)", "Moderate level of need" (3), "High level of need" (4). The omega coefficients were calculated for this latent variable as 0,84, 0,78, and 0,90 for Estonia, Japan, and Turkey, respectively. The low level of need and moderate level of need were combined to indicate "no need" (1) and moderate level of need and high level of need were combined to indicate "need" (0).

Workplace well-being and stress: The items that were included under this latent variable were presented by asking teachers to the frequency of the following occur. The items were presented as follow:

(a) I experience stress in my work

(b) My job leaves me time for my personal life

(c) My job negatively impacts my mental health

(d) My job negatively impacts my physical health

The response alternatives that were presented to the teachers were stated as "not at all" (1), "to some extent" (2), "quite a bit" (3), "a lot" (4). The omega coefficients were calculated as $0.84,0.89$, and 0.83 for Estonia, Japan, and Turkey, respectively. The response options of not at all and to some extent were combined to indicate "no stress" $(0)$ and "quite a bit" and "a lot" were combined to indicate "stress". 
Experience of teachers: In this study, as categorized in the literature (Rosenholtz and Simpson, 1990), teachers who have an experience from 1 to 5 years were categorized as novice teachers, teachers who have an experience from 6 to 10 years were labelled as mid-career teachers, and teachers who have an experience more than 11 years were categorized as veteran teachers.

\section{Data Analysis}

In this study, multiple logistic regression was run to understand which variables affect teacher's self-efficacy to be low or high (Pallant, 2011). The probabilities of science teachers' self-efficacy in instruction and their self-efficacy in student engagement based on a set of predictors were investigated for Estonia, Japan, and Turkey.

For the first research question, multiple logistic regression was performed to reveal the effects of professional collaboration among teachers, teacher-student relations, teachers perceived disciplinary climate, teachers needs for professional development in subject matter and pedagogy, teachers' wellbeing and stress, teachers' experience, and teachers' gender (hereafter "set of variables") on science teachers' odds of having high self-efficacy in Estonia, Japan, and Turkey. Model 1 for the first research question can be expressed as:

$\operatorname{Pr}\left(\right.$ Self-efficacy in instruction $\left.{ }_{t}=1\right)=$

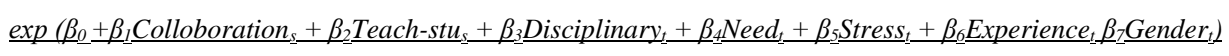

$1+\exp \left(\beta_{0}+\beta_{1}\right.$ Colloboration $_{s}+\beta_{2}$ Teach-stu $_{s}+\beta_{3}$ Disciplinary $_{t}+\beta_{4}$ Need $_{t}+\beta_{5}$ Stress $_{t}+\beta_{6}$ Experience $_{t} \beta_{7}$ Gender $\left._{t}\right)$

Multiple logistic regression was performed again to reveal the effect of same set of explanatory variables on science teachers' odds of having high self-efficacy in Estonia, Japan, and Turkey (second research question). Model 2 for the first research question can be expressed as;

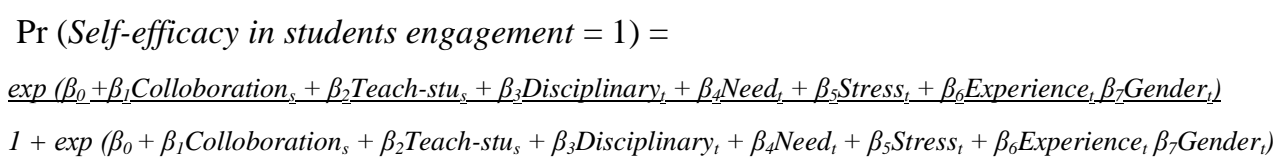

Self-efficacy in instruction $n_{t}$ and Self-efficacy in students engagement $t_{t}$ indicate two-level categorical variables in which whether teacher $t$ in Estonia, Japan or Turkey has a high self-efficacy in two dimension; colloboration ${ }_{\mathrm{s}}$ is the collaboration among teachers in school $s$; Teach-stu $\mathrm{s}_{\mathrm{s}}$ is the student teacher relations in school $s$, Disciplinary $\mathrm{t}_{\mathrm{t}}$ is defined as the teachers' perceived disciplinary climate, $\mathrm{Need}_{t}$ is the teachers needs for professional development in subject matter and pedagogy, Stress $t$ is the teachers stress, Experience ${ }_{t}$ is the teachers' experience, Gender ${ }_{t}$ is the teachers' gender.

\section{Results}

The sample of the study includes 1637 science teachers from Estonia, Japan, and Turkey (Estonia $=541$, Japan $=498$, and Turkey $=598$ ). The percentages of science teachers regarding to gender, experience was presented in Table 1 . The percentages of female science teachers are $80,8 \%, 29,4 \%$, and $55,5 \%$ in Estonia, Japan, and Turkey, respectively. As its seen in the Table 1, the number of science teachers regarding to the experience in Japan and Turkey are similar to each other. However, the percentages of veteran teachers in Estonia is nearly $20 \%$ higher than the percentages of veteran science teachers in Japan and Turkey.

\section{Table 1}

Percentages of science teachers regarding to gender and experience

\begin{tabular}{lrrrc}
\hline & $\begin{array}{c}\text { Estonia } \\
\mathrm{N}=541\end{array}$ & $\begin{array}{c}\text { Japan } \\
\mathrm{N}=498\end{array}$ & $\begin{array}{c}\text { Turkey } \\
\mathrm{N}=598\end{array}$ & $\begin{array}{c}\text { Total } \\
\mathrm{N}=1637\end{array}$ \\
\hline Gender & & & & \\
Female & 80,8 & 29,4 & 55,5 & 44,9 \\
Male & 19,2 & 70,5 & 44,5 & 55,1 \\
Experience of science teachers & & & & \\
Novice (1-5 years) & 12,8 & 23,8 & 23,1 & 28,62 \\
Mid-career (6-11 years) & 12,1 & 19,9 & 20,9 & 25,9
\end{tabular}


Veteran (more than 11 years)

75,1

56,2

55,9

45,4

In Table 2, the percentages of science teachers who have low and high self-efficacy in instruction and self-efficacy in student engagement were presented. Whereas the percentage of teachers who have high self-efficacy in instruction is highest in Japan among the three countries, the percentages of teachers who have high self-efficacy in student engagement are so close to each other in Estonia and Japan. The percentages of teachers who have high self-efficacy in student engagement is the lowest in Turkey when compare to Estonia and Japan.

\section{Table 2}

The Percentages of science teachers regarding to the Self-efficacy in Instruction and Self-efficacy in student engagement

\begin{tabular}{lrrrc}
\hline & $\begin{array}{c}\text { Estonia } \\
\mathrm{N}=541\end{array}$ & $\begin{array}{c}\text { Japan } \\
\mathrm{N}=498\end{array}$ & $\begin{array}{c}\text { Turkey } \\
\mathrm{N}=598\end{array}$ & $\begin{array}{c}\text { Total } \\
\mathrm{N}=1637\end{array}$ \\
\hline Self-efficacy in instruction & & & & \\
Low self-efficacy & 63,8 & 48,7 & 51 & 50,2 \\
High self-efficacy & 36,2 & 51,3 & 49 & 49,8 \\
Self-efficacy in student engagement & & & & \\
Low self-efficacy & 58,4 & 58,2 & 51,3 & 54,4 \\
High self-efficacy & 41,6 & 41,7 & 48,6 & 45,6 \\
\hline
\end{tabular}

For the first research question, multiple logistic regression was run regarding to the first model to reveal the effect of set of variables (professional collaboration among teachers, teacher-student relations, teachers perceived disciplinary climate, teachers needs for professional development in subject matter and pedagogy, teachers' well-being and stress, teachers' experience, and teachers' gender) on science teachers' self-efficacy in instruction in Estonia, Japan, and Turkey. Table 3 presents the variables in the first model and the odds ratios that corresponds to these variables.

In Estonia, the odds ratio was estimated $2.05(\mathrm{OR}=2.05 ; \mathrm{CI}: 1.40-2.98, \mathrm{p}<0.05)$ for the explanatory variable of "professional collaboration in lessons among teachers" which is the highest among the three countries. This means that teachers who told that there is a professional collaboration in lessons among teachers, in other words there is a collaboration culture among teachers, have more than 2 times the odds of having high self-efficacy in instruction comparing the science teachers who told that there is not any collaboration among teachers. So, the effect of the professional collaboration among teachers on science teachers' self-efficacy in instruction is the highest when compare to Japan and Turkey. In addition, in Estonia, science teachers who are working in the school in which the teacher and students' relations are good have more than 2 times the odds of having high self-efficacy in instruction when compare to the teachers who are working the school in which the teacher-student relations are poor $(\mathrm{OR}=2.21, \mathrm{CI}: 1.50-2.25, \mathrm{p}<0.05)$. Moreover, in Estonia, the science teachers who thought that they are working in a disciplined school have $61 \%$ greater odds of having self-efficacy in instruction $(\mathrm{OR}=1.61$; $\mathrm{CI}: 1.09-2.38, \mathrm{p}<0.05)$. Lastly, in Estonia, the science teachers who have getting experience in their teaching career have $43 \%$ lower odds of having high self-efficacy in instruction in Estonia (OR $=0.57$; CI: $0.44-075, \mathrm{p}<0.05)$.

Table 3

Estimated odds ratio for the teachers who have high self-efficacy in instruction

\begin{tabular}{|c|c|c|c|}
\hline & Estonia & Japan & Turkey \\
\hline Professional Collaboration & $2.05^{*}$ & 1.01 & $1.43^{*}$ \\
\hline Teach-student relations & $\begin{array}{l}(0.2) \\
2.21 *\end{array}$ & $\begin{array}{l}(0.2) \\
1.77 *\end{array}$ & $\begin{array}{l}(0.2) \\
2.79 *\end{array}$ \\
\hline Disciplinary climate & $\begin{array}{l}(0.2) \\
1.61 * \\
(0.2)\end{array}$ & $\begin{array}{l}(0.2) \\
1.50 * \\
(0.2)\end{array}$ & $\begin{array}{l}(0.2) \\
1.22 \\
(0.2)\end{array}$ \\
\hline Need for PD in subject and pedagogy & $\begin{array}{l}0.77 \\
(0.2)\end{array}$ & $\begin{array}{l}1.03 \\
(0.2)\end{array}$ & $\begin{array}{l}1.92^{*} \\
(0.2)\end{array}$ \\
\hline Teachers well-being and stress & $\begin{array}{l}089 \\
(0.2)\end{array}$ & $\begin{array}{l}0.82 \\
(0.2)\end{array}$ & $\begin{array}{l}0.97 \\
(0.2)\end{array}$ \\
\hline Teachers' experience & & $\begin{array}{l}1.42 * \\
(0.1) \\
0.72\end{array}$ & $\begin{array}{l}0.87 \\
(0.1) \\
1.07\end{array}$ \\
\hline Gender of teachers & $\begin{array}{l}1.25 \\
(0.2)\end{array}$ & $\begin{array}{l}0.72 \\
(0.2)\end{array}$ & $\begin{array}{l}1,07 \\
(0.2)\end{array}$ \\
\hline Intercept & $\begin{array}{l}0.92 * \\
(0,4)\end{array}$ & $\begin{array}{l}0.36^{*} \\
(0.3) \\
\end{array}$ & $\begin{array}{l}0.41^{*} \\
(0.3)\end{array}$ \\
\hline
\end{tabular}


$*_{\mathrm{p}}<0.05$. Standard errors shown in parenthesis.

In Japan, the odds ratio was estimated $1.77(\mathrm{OR}=1.77$; CI: $1.18-2.66, \mathrm{p}<0.05)$ for the explanatory variable of "teacher-student relations". This value indicates that science teachers who are working in the school in which the teacher and students' relations are good have $77 \%$ greater odds of having selfefficacy in instruction than science teachers who are working in a school in which the teacher-students relations are poor. In addition, science teachers who are working in a disciplined school have 50\% greater odds of having high self-efficacy in instruction than the science teachers who are working in school to be thought not disciplined (OR = 1.95; CI: $1.02-2.19, \mathrm{p}<0.05)$. Moreover, teachers who are getting experience in their teaching career have $42 \%$ greater odds of having high self-efficacy in instruction $(\mathrm{OR}=1.42$; $\mathrm{CI}: 1.13-1,79, \mathrm{p}<0.05)$.

In Turkey, science teachers who are working in a school that the professional collaboration among teachers was encouraged have $43 \%$ greater odds of having high self-efficacy in instruction than the science teachers who are working in a school in which there is not any collaboration culture among teachers in the school ( $\mathrm{OR}=1.43 ; \mathrm{CI}: 1.01-2.03$, $\mathrm{p}<0.05)$. In addition, in Turkey, science teachers who are working in a school in which the teacher-student relations are good have more than 2.5 times the odds of having high self-efficacy in instruction comparing the science teachers who are working in which the teacher-student relations are poor $(\mathrm{OR}=2.79$; CI: $1.92-4.05, \mathrm{p}<0.05)$. Moreover, in Turkey, science teachers who told that they do not need any professional development in subject matter and pedagogy have $92 \%$ greater odds of having high self-efficacy in instruction than teachers who thought that they need professional development in subject matter and pedagogy $(\mathrm{OR}=1.92$; CI: $1.34-2.76$, $\mathrm{p}<0.05)$.

For the second research question, multiple logistic regression was performed to investigate the effects of set of variables on science teachers' self-efficacy in student engagement in Estonia, Japan, and Turkey. Table 4 included the variables in the second model and the corresponding odds ratios.

\section{Table 4}

Estimated odds ratio for the teachers who have high self-efficacy in student engagement

\begin{tabular}{llll}
\hline & Estonia & Japan & Turkey \\
\hline Professional Collaboration & $2.12^{*}$ & $1.65^{*}$ & $1.54^{*}$ \\
Teach-student relations & $(0.2)$ & $(0.2)$ & $(0.2)$ \\
& $2.40^{*}$ & $(.44$ & $3.56^{*}$ \\
Disciplinary climate & $(0.2)$ & $(0.2)$ & $(0.2)$ \\
Need for PD in subject and pedagogy & 1.41 & $\left(0.70^{*}\right.$ & 1.13 \\
& $(0.2)$ & 1.10 & $(0.2)$ \\
Teachers well-being and stress & 0.99 & $(0.2)$ & $2,64^{*}$ \\
Teachers' experience & $(0.2)$ & 0.89 & $(0.2)$ \\
Gender of teachers & 0.98 & 1.24 & $(0.2)$ \\
Intercept & $(0.2)$ & $(0.8)$ & 0.93 \\
& $(0.1)$ & $0.57^{*}$ & $(0.1)$ \\
\hline
\end{tabular}

$* \mathrm{p}<0.05$. Standard errors shown in parenthesis.

In Estonia, science teachers who are working in a school in which professional collaboration among teachers is encouraged have more than 2 times the odds of having high self-efficacy in student engagement comparing the science teachers in which there is nor any collaboration culture among teachers in the school $(\mathrm{OR}=2.12$; CI from $1.47-3.05, \mathrm{p}<0.05)$. In addition, science teachers who are working in a school in which teacher-student relation are good have nearly 2.5 times the odds having high self-efficacy in student engagement comparing the science teachers who are working in a school in which teacher-student relations are poor $(\mathrm{OR}=2.40 ; \mathrm{CI}: 1.65-3.50, \mathrm{p}<0.05)$. 
In Japan, science teachers who are working in a school in which professional collaboration among teachers is encouraged have $65 \%$ greater odds of having high self-efficacy in student engagement comparing the science teachers in which there is nor any collaboration culture among teachers in the school (OR $=1.65$; CI: $1.13-2,42, \mathrm{p}<0.05)$. In addition, science teachers who are working in a disciplined school have $70 \%$ greater odds of having high self-efficacy in instruction than the science teachers who are working in school to be thought not disciplined (OR = 1.70; CI: $1.14-2.52$, p $<0.05$ ). Moreover, teachers who are getting experience in their teaching career have $47 \%$ greater odds of having high self-efficacy in student engagement $(\mathrm{OR}=1.47$; CI: $1.15-1,87, \mathrm{p}<0.05)$. Moreover, in Japan, female teachers have $43 \%$ lower odds of having high self-efficacy in student engagement than male teachers $\mathrm{OR}=0.57$; CI: $0.37-0.87, \mathrm{p}<0.05$ ).

In Turkey, science teachers who are working in a school in which professional collaboration among teachers was encouraged have 54\% greater odds of having high self-efficacy in student engagement than the science teachers who are working in a school in which there is not any collaboration culture among teachers in the school (OR $=1.54$; CI: $1.07-2.20, p<0.05)$. In addition, in Turkey, science teachers who are working in a school in which the teacher-student relations are good have more than 3.5 times the odds of having high self-efficacy in student engagement comparing the science teachers who are working in which the teacher-student relations are poor (OR $=3.56$; CI: 2.41 $-5.28, \mathrm{p}<0.05)$. Moreover, in Turkey, science teachers who told that they do not need any professional development in subject matter and pedagogy have more than 2.5 times the odds of having high selfefficacy in instruction than teachers who thought that they need professional development in subject matter and pedagogy $(\mathrm{OR}=2.64$; $\mathrm{CI}: 1.82-3.82, \mathrm{p}<0.05)$.

\section{Discussion, Conclusion and Recommendations}

The effectiveness of the teachers' high self-efficacy were expressed regarding to instructional quality (Holzberger, Philipp and Kunter, 2013), teachers' job satisfaction and their commitments (Avanzi et al., 2013), and students' achievement and motivation (Caprara et al., 2006). Although it is believed that self-efficacy is an unidimensional concept, the importance of investigating teachers' selfefficacy within the multidimensional framework was emphasized due to the teaching practices includes several aspects (Klassen et al., 2011). Revealing the factors that have a potential to effect dimensions of the self-efficacy is very crucial since it is importance on educational outcomes. For instance, the effect of school climate on teachers' self-efficacy was also expressed in some studies (Bandura, 1997; Malinen \& Savolainen, 2016).

This study was conducted to understand the effects of school climate related variables such as professional collaboration among teachers, teacher-student relations, and teachers perceived disciplinary climate on science teachers' self-efficacy in instruction and self-efficacy in student engagement. In addition, some of the indicators related to sources of self-efficacy such as teachers' need of professional development in content and pedagogy and teachers' workplace well-being and stress was also examined with their effects on science teachers' self-efficacy in instruction and self-efficacy in student engagement. Moreover, lastly, the effects of teachers' background characteristics such as experience and gender on science teachers' self-efficacy in instruction and self-efficacy in student engagement was examined.

Although school climate is stated as a multidimensional concept, in TALIS 2018, it was preferred capture school climate mainly by the indicators of teacher-student relations, classroom disciplinary climate, participation of stakeholders to the school decision (Ainley and Carstens, 2018; OECD, 2019). In another study, Malinen and Savolainen (2016) included collaboration among teachers, student relationship, decision making, and instructional innovation to capture general school climate.

In this study, the indicators about professional collaboration among teachers, teacher-student relations, and disciplinary climate were selected to capture school climate. For the first model, the results revealed that among these variables, the effect of teacher-student relations on science teachers' selfefficacy in instruction is significant for Estonia, Japan, and Turkey. Science teachers who are working in the school in which teacher-student relations are good have more than 2 times odds of having high self-efficacy in instruction in Estonia and Turkey, have nearly 2 times odds of having high self -efficacy in instruction in Japan. In addition, science teachers who are working in a school in which professional 
collaboration is enhanced have 2 times odds of having high self-efficacy in instruction comparing the science teachers who are working in a school in which the professional collaboration is not emphasized in Estonia. Moreover, science teachers who are working in a disciplined school have $61 \%$ greater odds and 50\% greater odds of having high self-efficacy in instruction in Estonia and Japan, respectively. For the second model, the results revealed that among the school climate variables the effect of professional collaboration among teachers on science teachers' self-efficacy engagement is significant for all three countries. As similar to the fist model, teacher-student relations is very important especially Estonia and Turkey with its effect on science teachers self-efficacy in students engagement.

As Bandura (2012) expressed that the circumstances in which teaching occurs are strongly related with teachers' self-efficacy, many studies reported the positive association between self-efficacy and school climate (Collie, Shapka, and Perry 2012; Meristo and Eisenschmidt 2014). In addition, Wilson, Woolfson, and Durkin (2018) expressed that school environment is very crucial and examined to investigate the development of self-efficacy. They asserted that school environment which is positive and supportive lead teachers to feel capable of working with students. In another study, Malinen and Savolainen (2016) found high correlations between school climate to collective efficacy in student discipline and moderate correlation with self-efficacy in managing behavior. So, the results of this study show consistency with previous studies that was related to the effect of school climate on teachers' selfefficacy.

In both models, the results reveal that the effect of professional collaboration among teachers has greatest effect in Estonia comparing to Japan and Turkey. In a study which is conducted to investigate school environmental factors that have a potential to support the innovative behaviors of teachers in Estonia based on the TALIS 2013 data, revealed the association of teachers' self-efficacy and professional collaboration among teachers (Nemeržitski , Loogma, Heinla \& Eisenschmidt, 2013). In this study, it was revealed that the effect of professional collaboration among teachers and teacher student relations on both dimensions of science teachers' self-efficacy was found significant, on the other hand, the effect of disciplinary climate on both dimensions on self-efficacy was found nonsignificant. However, in a study (Arslan, 2015) which is conducted to investigate the relationship between factors related to the school climate with the teachers' self-efficacy based on the TALIS 2008 data in Turkey and Korea, revealed that one best construct that explains teachers' self-efficacy is disciplinary climate for Turkey. Although the results of Aslan's (2015) study show some contradictions with the findings of this study, the influence of professional collaboration among teachers and teacher student relations on teachers' self-efficacy were also expressed for Turkey.

As it was indicated before, there is a robust relationship between teachers' self-referent subject matter knowledge and higher levels of self-efficacy (Rice and Roychoudhury, 2003). In this study, teachers' need for professional development in subject matter and pedagogy was used to reveal teachers' self-refence evaluation about teacher needs in this issue. Teachers who do not need any professional development was evaluated as they feel sufficient in subject matter and pedagogy. The significant results only yielded in Turkey among three countries for this variable which means that science teachers who do not need any professional development in subject matter or pedagogy have greater odds of having high self-efficacy in instruction and in student engagement. The importance of mastery experience for higher self-efficacy of teachers was also indicated in the literature (Tschannen-Moran and McMaster 2009). On other hand, the non-significant odds ratios yielded in this variable for Estonia and Japan could be explained by the Henson's (2002) expression of practically nonexistent research on exploring the sources of self-efficacy.

Although the effect of teacher's experience yielded non-significant results on sciences teachers' self-efficacy in instruction and student engagement for Turkey, significant odds ratios were gathered for Estonian and Japanese science teachers. Whereas, in Estonia, science teachers who are getting experience in their teaching career have lower odds of having high self-efficacy, in Japan, science teachers who are getting experience in their teaching career have greater odds of having high selfefficacy in instruction.

The findings of this study supported the some of the components' effects of school climate on science teacher's self-efficacy in instruction and in student engagement. However, the degree of the 
odds of having high self-efficacy related to these components varies across the countries. Therefore, longitudinal studies are recommended to investigate the trend of these effects within a country and across the countries regarding to multidimensional aspects of science teachers' self-efficacy. International large-scale assessments give researchers opportunities to get fruitful findings on science teachers self-efficacy.

\section{References}

Ainley, J. and R. Carstens (2018), "Teaching and Learning International Survey (TALIS) 2018 Conceptual Framework", OECD Education Working Papers, No. 187, OECD Publishing, Paris. http://dx.doi.org/10.1787/799337c2-en

Aslan, B. (2015). A comparative study on the teaching profession in Turkey and South Korea: Secondary analysis of TALIS 2008 data in relation to teacher self-efficacy. Eurasian Journal of Educational Research, 61, 1-22 http://dx.doi.org/10.14689/ejer.2015.61.1

Avery, L. M., \& Meyer, D. Z. (2012). Teaching science as science is practiced: Opportunities and limits for enhancing preservice primary teachers' self-efficacy for science and science teaching. School Science and Mathematics, 112(7), 395-409. http://dx.doi.org/10.1111/j.1949-8594.2012.00159.x

Bandura, A. (1997). Self-efficacy: The exercise of control. NY: W.H. Freeman and Co.

Bandura, A. (2012). On the functional properties of perceived self-efficacy revisited [Editorial]. Journal of Management, 38(1), 9-44. https://doi.org/10.1177/0149206311410606

Caprara, G. V., Barbaranelli, C., Steca, P., \& Malone, P. S. (2006). Teachers' self-efficacy beliefs as determinants of job satisfaction and students' academic achievement: A study at the school level. Journal of School Psychology, 44, 473-490. https://doi.org/ 10.1016/j.jsp.2006.09.001.

Collie, R. J., J. D. Shapka, \& N. E. Perry. 2012. "School Climate and Social-Emotional Learning: Predicting Teacher Stress, job Satisfaction, and Teaching Efficacy." Journal of Educational Psychology 104: 1189-1204. doi:10.1037/a0029356.

Ford, D. J., Fifield, S., Madsen, J., \& Qian, X. (2013). The science semester: Crossdisciplinary inquiry for prospective primary teachers. Journal of Science TeacherEducation, 24, 1049-1072. http://dx.doi.org/10.1007/s10972-012-9326-8

Henson, R. K. (2002). From Adolescent Angst to Adulthood: Substantive Implications and Measurement Dilemmas in the Development of Teacher Efficacy Research, Educational Psychologist, 37:3, 137-150, DOI: 10.1207/S15326985EP3703_1

Holzberger, D., A. Philipp, \& M. Kunter (2013), "How teachers' self-efficacy is related toinstructional quality: A longitudinal analysis", Journal of Educational Psychology, Vol. 105/3, pp. 774-786, http://dx.doi.org/10.1037/a0032198.

Klassen, R.M., Tze, V.M.C., Betts, S.M., \& Gordaon, K.A. (2011), “Teacher efficacy research 19982009: Signs of progress or unfulfilled promise?", Educational Psychology Review, Vol. 23/1, pp. 21-43, http://dx.doi.org/10.1007/s10648-010-9141-8.

Malinen, O. P., Savolainen, H., Engelbrecht, P., Xu, J., Nel, M., Nel, N., ... Tlale, D. (2013). Exploring teacher self-efficacy for inclusive practices in three diverse countries", Teaching and Teacher Education, Vol. 33, pp. 34-44.

Malinen, O.-P., \& Savolainen, H. (2016). The Effect of Perceived School Climate and Teacher Efficacy in Behavior Management on Job Satisfaction and Burnout: A Longitudinal Study. Teaching and Teacher Education, 60, 144-152. https://doi.org/10.1016/j.tate.2016.08.012

Meristo, M., and E. Eisenschmidt. 2014. "Novice Teachers' Perceptions of School Climate and SelfEfficacy.” International Journal of Educational Research 67: 1-10. doi:10.1016/j.ijer.2014.04.003.

Nemeržitski , K. Loogma , E. Heinla \& E. Eisenschmidt (2013) Constructingmodel of teachers' innovative behaviour in school environment, Teachers and Teaching, 19:4,398-418, DOI: 10.1080/13540602.2013.770230

OECD (2019a), PISA 2018 Results (Volume I): What Students Know and Can Do, PISA, OECD Publishing, Paris, https://doi.org/10.1787/5f07c754-en. 
OECD (2019b). TALIS 2019 Technical Report. PISA, OECD Publishing, Paris. Retrieved from the OECD website: https://www.oecd.org/education/talis/TALIS_2018_Technical_Report.pdf

Pallant, J. (2011) SPSS survival manual: A step by step guide to data analysis using the SPSS program. 4th Edition, Allen \& Unwin, Berkshire.

Palmer, D., Dixon, J., \& Archer, J. (2015). Changes in Science Teaching Self-efficacy among Primary Teacher Education Students. Australian Journal of Teacher Education, 4O(12).http://dx.doi.org/10.14221/ajte.2015v40n12.3

Petersen, J. E., \& Treagust, D. F. (2014). School and University Partnerships: The Role of Teacher Education Institutions and Primary Schools in the Development of Preservice Teachers' Science Teaching Efficacy. Australian Journal of Teacher Education, 39(9). http://dx.doi.org/10.14221/ajte.2014v39n9.2

Rice, D. C., \& Roychoudhury, A. (2003). Preparing more confident preservice primary science teachers: One primary science methods teacher's self-study. Journal of Science Teacher Education, 14, 97126. http://dx.doi.org/10.1023/A:1023658028085

Rosenholtz, S. J., \& Simpson, C. (1990). Workplace conditions and the rise and fall of teachers' commitment. Sociology of Education, 63(4), 241-257.

Settlage, J., Southerland, S. A., Smith, L. K., \& Ceglie, R. (2009). Constructing a doubt-free teaching self: Self-efficacy, teacher identity, and science instruction within diverse settings. Journal of Research in Science Teaching, 46(1), 102-125. http://dx.doi.org/10.1002/tea.20268

Skaalvik, E., \& S. Skaalvik (2010), "Teacher self-efficacy and teacher burnout: A study ofrelations", Teaching and Teacher Education, Vol. 26/4, pp. 1059-1069, http://dx.doi.org/10.1016/j.tate.2009.11.001.

Tosun, T. (2000). The beliefs of preservice primary teachers towards science and science teaching. School Science and Mathematics, 100, 374-379. http://dx.doi.org/10.1111/j.19498594.2000.tb18179.x

Tschannen-Moran, M., \&A. Hoy (2001), “Teacher efficacy: Capturing an elusive construct”,Teaching and Teacher Education, Vol. 17/7, pp. 783-805, https://doi.org/10.1016/S0742- 051X(01)000361 .

Tschannen-Moran, M., \& P. McMaster. (2009). "Sources of Self-Efficacy: Four Professional Development Formats and Their Relationship to Self-Efficacy and Implementation of a new Teaching Strategy.” The Elementary School Journal 110: 228-245.

Tschannen-Moran, M., Woolfolk Hoy, A., \& Hoy, W. K. (1998). Teacher efficacy: Its meaning and measure. Review of Educational Research, 68, 202-248.

Usher, E., \& F. Pajares (2008), "Sources of self-efficacy in school: Critical review of theliterature and future directions", Review of Educational Research, Vol. 78/4, pp. 751-796, http://dx.doi.org/10.3102/0034654308321456. 
